\title{
Impact of WhatsApp on Learning and Retention of Collocation Knowledge among Iranian EFL Learners
}

\author{
Zahra Ashiyan \\ English Department, Faculty of Humanities, Najafabad Branch, Islamic Azad University, Najafabad, Isfahan, Iran \\ Hadi Salehi (Corresponding author) \\ English Department, Faculty of Humanities, Najafabad Branch, Islamic Azad University, Najafabad, Isfahan, Iran \\ E-mail: hadisalehi1358@yahoo.com
}

Doi:10.7575/aiac.alls.v.7n.5p.112

URL: http://dx.doi.org/10.7575/aiac.alls.v.7n.5p.112
Received: $27 / 05 / 2016$

Accepted: 06/08/2016

\begin{abstract}
During the recent technological years, language learning has been attempted to transform its path from the conventional methods to instrumental applications. Mobile phone provides people to reach and exchange information through chats (WhatsApp). It is a tool or mode that means the facilities are used for main purposes. The unique features of the application are its compatibility to exchange information, enhance communication and relationship. A mobile phone provides to download, upload and store learning materials and information files. The purpose of the current study was to investigate the use and effect of mobile applications such as WhatsApp on school work and out of school work. In this way, Oxford Placement Test (OPT) was conducted among 80 learners in order to select intermediate EFL learners. In total, 60 participants whose scores were 70 or higher were elected as the intermediate level and were divided into experimental and control groups. In order to control the reliability of the collocation pretest, the test was pilot studied on 15 learners. Then, the pretest was conducted to measure the learner's collocation knowledge in both of the groups. The experimental group frequently installed WhatsApp application in order to learning and practicing new collocations in order to learning and practicing new collocations, while the control group did not use any tool for learning them. An immediate posttest after the treatment was administered. The results in each group were statistically evaluated and the findings manifested that the experimental group who used WhatsApp application in learning collocation significantly outperformed the control group in posttest. Thus usage of WhatsApp application to acquire collocations can reinforce and enhance the process of collocations acquisition and it can guarantee retention of collocations. This study also prepares pedagogical implications for utilizing mobile application as an influential instrument in learning a second language.
\end{abstract}

Keywords: Mobile application, WhatsApp, Collocations knowledge, Information and Communication Technology (ICT), Iranian EFL learners, Social Networking Sites (SNSs)

\section{Introduction}

Using social networking including mobile applications have been utilized to improve students' progress in different language skills and sub-skills consisting vocabulary, pronunciation, reading and listening. But these applications have to a very lower extent- been used in Iran; however, the problem is that compared with the number of application users who are growing every day, the number of studies conducted on the usage of social applications for language learning is so rare. To the best of the present researcher's knowledge none of the studies performed so far have investigated the effectiveness of social networking sites such as WhatsApp on learning collocations among Iranian EFL learners. Several studies have claimed that the employment of modern technologies in education is principal in the information era (Salehi \& Salehi, 2012). As Garret (1991) acknowledged, "The integration of ICT in teaching and learning is not a method; rather it is a medium in which variety of methods, approaches and pedagogical philosophies may be implemented". This statement indicates that the usefulness of ICTs relates on how and why it is implemented and combined (Salehi \& Salehi, 2012). On the other hand, with the rapid progress of wireless and mobile learning technology throughout the world, the usage of mobile phone and the other portable means are recently beginning to have an effect on language teaching and learning. Similarly, the growth of language learning technologies newly has changed to be mobilized, portable, and personalized (Yousefzadeh, 2012). The perspective of how learners can expand collocation knowledge has been progressed by social networking sites (SNSs). Presently, the opportunity to broaden the conception of collocation knowledge is at hand by technology. The difficult task facing learners is to reinforce practical language proficiency out of the classroom. SNSs according to Andreas Kaplan refer to the manner of interactions among population in which they generate, share and/or change data and opinions in virtual societies and network. This popularity should aid SNSs performance as ordinary assistances for educational actions if they are operated successfully. WhatsApp is one of the evolutions in technology that is universally employed on specified mobile phones and computers. The implementation of WhatsApp is the most widespread messenger applications among the college 
scholars (Jadhav, Bhutkar, \& Mehta, 2013). The total objective of the study was to increase our comprehension of the probable and challenges of educational applications that includes WhatsApp-supported information sharing. Language is a complicated network consisting of sounds, words, and grammar, but learning vocabulary and its collocations is an arguable concern in this complex realm. Furthermore, there is a profound relationship between vocabulary size and the skills of listening, speaking, reading and writing. According to Zimmermann (1994), vocabulary is central to language learner. Allen (1983, p.14) asserted that "The need for vocabulary learning is one point on which the teachers and students agree on it". Therefore, vocabulary acquiring has a functional role in different stages of foreign language learning. Learners can speak but misinterpretation was unavoidable because of absence of mastery of words and its collocations. It is chiefly accepted that collocations participate in a vital role in second language learning, mainly at the intermediate and advanced levels corresponding of L1 collocations. In the situation of a foreign language background such as Iran, collocational proficiency can be profitable as it assists the learners develop their language mastery. Researchers concur about the substantial worth of this knowledge for second language learners (Durrant \& Schmitt, 2009). Second language speakers who would interest to achieve native-like fluency should consider to collocations in speaking so that they might not construct sentences that sound strange to native speakers. It can be concluded that the mastery and application of collocations is a prime matter in language proficiency. This study is an attempt to address whether using WhatsApp has significant effects on improving Iranian EFL learners' collocation knowledge.

\section{Literature Review}

The rapid development of computers and associated technology have been caused the extensively usage of Information Communication and Technology (ICT) in the education and training context (Salehi, Shojaee \& Sattar, 2015). Altogether computers have turned into an undoubtedly tool for living and education field. It emerges that ICT education is essential for persons to be regular in the Computer Education period. By supported the latest technology, the individuals are able to interact with one another via online. Therefore; the integration of ICT in teaching and learning prepares further chances for teachers and students to try in an information era (Salehi \& Salehi, 2012). On balance ICT has the function to initiate new teaching and learning exercise because ICT performs as a catalyst of transforming of the education system (Trucano, 2005). The pedagogical features demonstrate that the shift of knowledge and information by ICT is an uncomplicated instrument of delivery and the creation of fresh knowledge is achievable by means of this innovative usage of ICT (Duus, 2009). Wholly, in this connection ICT will support the concept of Technology Enhanced Learning (TEL).

Due to the widespread use of Information and Communication Technologies (ICTs) and the Internet, many areas of education world in general and language teaching and learning in particular have undergone a major shift in all its aspects (Kajornboon, 2013). Nowadays, in order to be in line with the current trends and changes, the L2 practitioners have to welcome and incorporate the new technology and its vast possibilities (Zhihong, Leijuan, \& Xiaohui, 2010). The development in universal computer networks has prompted a massive increase in online language learning. The interactive abilities of computer-mediated communication tools have encouraged the study of language learning in textbased chat, massively multiple online gaming, and mobile devices (Sykes, Oskoz \& Thorne, 2008).

Being an extensive concept in everyday life and a part of learners' lives, social networks play an indispensable role and have the potentiality to improve learners' learning and to enrich the learning contexts in a number of ways (Goldfarb, Pregibon, Shrem, \& Zyko, 2011). The use of social networking in generating online communities is very popular among L2 practitioners. Similarly, the L2 learners create social groups and simulate learning contexts by using variety of social media to connect and communicate with others beyond the L2 classrooms (Sekiguchi, 2012). Having considered the popularity of social networks among L2 learners, it would be helpful to develop ways to utilize and make them effective in language teaching and learning. Increasingly, social networks have become a theme of investigation during the past few years (Selwyn, 2009; Smith, Salaway, \& Caruso, 2009). Srinivas (2010) stated that social networking as a modern tool is able to assist L2 teachers and learners to access information and facilitate the language teaching and learning.

A great deal of the work in the past on predicting language learning success has focused on the influence of social networks on L2 learners' communicative ability (Goldfarb, Pregibon, Shrem, \& Zyko, 2011). Recently, as an emerging subject of considerable interest within individual differences research, the study of social networking and its influence on language learning is tinted in academic success. Sekiguchi (2012) asserted that social media have a remarkable role in the future of language learning and teaching curriculum. However, he added that a sound language curriculum needs to be built on the pedagogical principles and educational psychology. The purpose, appropriateness, multimodality, and sustainability of the technology should be considered to build a language curriculum based on the current principles of language teaching and learning (Sekiguchi, 2012). The social networks are able to help EFL teachers to make their best efforts to blend technologies and identify barriers to technology integration.

In fact nowadays, using technology in second language teaching and learning is the dominant language teaching/learning debates. Certainly, there is a vast body of research devoted to effects of technology on second language acquisition; however, a small number of them related to the effects of cell-phone on SLA (Yousefzadeh, 2012). Accordingly, learning forms have changed from traditional classroom learning to electronic learning (E-learning) and mobile learning (M-learning). Through these effective learning forms, mobile learning is beneficial and flexible; namely, mobile learning can overcome limitations of time and space, and empower learners to study whenever and wherever feasible (Chen \& Chung, 2007). While Cavus and Ibrahim (2009) declared that there is a rise use of wireless technologies in education all over the world. In fact, Wireless technologies such as laptops, computers and mobile 
phones are continually revolutionizing education and shifting the traditional classroom-based learning and teaching into anytime and anywhere education.

WhatsApp has become the "communication portal" for social networking that has quickly changed the way people communicate (Susilo, 2014). It is one of the evolutions which have been frequently used on particular mobile phones and computers (Yeboah \& Ewur, 2014). As an exclusive, cross-platform instant messaging subscription service which is available on the new generation of smart phones such as IPhone, Android, Blackberry and Nokia mobile phones, WhatsApp allows its users to send free text messages to each that is, users are not charged for a text sent through WhatsApp (Hindu, 2011). This is because WhatsApp sends messages through an internet data connection. It should be mentioned that many other, different message types, from simple text to pictures to audio files and videos as well as one's location using integrated mapping features are supported by WhatsApp (Alsaleem, 2014). With social networks rapidly gaining prominence in this scenario, WhatsApp is emerging as a tool that can be used for different educational purposes. WhatsApp is already being used to teach vocabulary or to disseminate general information and links for language learning.

\subsection{Learning through Mobile Application}

One of the most swiftly technology in the society is the cell phone with more than six billion subscribers (UN Report: 2013). Prensky (2001) acknowledged that a cell phone or cellular phone as a mobile phone is a tool that can build and receive telephone calls over a radio link while moving around a wide geographical area. Based on Sutee and Efparaxia (2014), "A smartphone is defined as a mobile device that allows users to make telephone calls, sends and receives emails, downloads files, provides an internet connection and uses applications." In other words, a broad variety of other services consist of text messaging, internet access, games, business application of cell phones and calendaring among other services (Kahari, 2013). Cell phones also include smart phone that it is a device makes calls but also adds Microsoft documents, QWERTY keyboard, synchronizing individual and professional e-mail accounts (Attwell, 2005). These devices are learners' habitual, daily means which are changing their first selection for entrancing the internet and making usage of communication services (Lundin et al., 2010; Melton \& Kendal, 2012). Recently, mobile learning is a multidisciplinary field of exploration that uses mobile gadgets for conversation, collaboration and instruction (Stowe, 2013). Hence, the use of mobile learning activities in online learning and teaching courses is an advanced training technology in higher education (Army, 2014).

Mobile learning which developed from the academic movement has started in the late 1990's and early 2000's (Stowe, 2013). Vygotsky (1978) asserted that "social constructivist theory attempts to improve social interactions between students to construct and share knowledge." The entry to learning materials anytime, anywhere and in mixed formats has the capability to reinforce deep student learning enhancement and to permit students to fabricate their own knowledge (Blehch, 2014). Learning is the consequence of social interactions between students in collaborative acquisition actions. These activities include sharing through mobile devices, like debate meetings (Chan, 2005) which can be utilized for knowledge establishment distribution (Gillingham \& Topper, 1999). The social interactions between online students are the basic construction of knowledge (Vygotsky, 1978).

McNeal and Hooft (2006) believed that cell phones as principal facilities that create training are more relevant and significant to enhancing students scholarly and numeracy skills. Traxler (2007) found that a structure of multiple literary which prepares a bridge between the real life texts of the society and formal learning thereby establishing a multimodal academic tactic to learning. Mobile learning technology is a modern revolution of remote learning. Researchers regard that the M-learning mode was selected by distance instruction teachers and is connected to the learning procedure operated by online tutor (Blehch, 2014).

Our students today are all 'native speakers' of the digital language of computers, Internet, video games, mobile phones and the other tools of the digital era (Prensky, 2001). College students habitually follow up to date instructional technologies in learning and devising knowledge. The transfer of common information through utilization of mobile technologies is more and more regular at universities and higher educational centers. Mobile learning also was called M-learning that is a new generation of distance learning focusing on the use mobile devices. It is a learning technology that employs different approaches of learning across social interactions (Vygotsky, 1978) with individual electronic devices (Crompton, 2013). Typically, mobile and web resources situate learning situations in reliable contexts, emphasize the interchange of opinions between participants and depend on the living encounter of the learner (Hartly \& Bendixen, 2001).

The mobile appliances equip learners with the opportunity to learn in different contexts and time (Crescente \& Lee, 2011). Mobile gadgets are applied at higher educational institutions like universities to develop online connections through exchange of views and to share knowledge between students by mobile communication modes such as instant messaging; via Mobile Social Networks and Web based learning (Echeverria, Nussbaum, Calderon, Bravo \& Infante, 2011). The mobile devises such as iPads, iPods, tablets, Mp3 players mobile phones and so on are used in mobile learning technologies. The mobile devices provide mobility and interactivity for students (Trentin \& Repetto, 2013).

Smart phones are not instructors by themselves; rather, they are instructional tools which have internet access, voice and text messaging, and voice recording. For the sake of learning a new language successfully, relatively the whole package of these characteristics can enable language learners to practice their communicative skills, benefiting from the privilege of genuine content, and task accomplishment. In the realm of research, these worthwhile benefits are very rare, or in other words it is an optimal situation that can hardly be found (Traxler, 2007). This is simply because cell phone 
users with internet connection can access a lot of documents at their convenience virtually anytime and anywhere within network coverage. They can therefore read online newspaper articles and short stories or novels now uploaded for the benefit of those whose cannot afford buying and reading newspapers and story books or novels from time to time. According to some L2 practitioners, reading good newspaper articles and story books or novels written by those with good knowledge and mastery of the language of communication is also a good way of improving the readers' knowledge and mastery of the language of communication (Oluga \& Oladipupo).

Nowadays, mobile phones have become a crucial part of our daily life. Every individual has a personal cell phone of their own. Mobile phones have been expanding rapidly since 1995 (Chowdhury, 2012). They are employed not only for sending text messages and making calls, but also for the other varieties of applications such as watch a movie, play music and access internet. Many operating systems such as Windows, Mobile, IOS and Android are developed to give more functionality in mobiles. Android applications are currently being developed (Susilo, 2014). The most popular messenger applications among the college students are consisted WhatsApp (WA), Skype and GO SMS Pro (Jadhaw, Bhutkar, \& Mehta, 2013). Technologies such as WhatsApp messages have achieved increasing prevalence in societies. These kinds of messaging technologies are greatly applied among undergraduate learners nowadays (Lenhart, 2007).

\subsection{Effect of WhatsApp as an Application on Learning}

Nowadays, mobile phones have become a crucial part of our daily life. Every individual has a personal cell phone of their own. Mobile phones have been expanding rapidly since 1995 (Chowdhury, 2012). They are employed not only for sending text messages and making calls, but also for the other varieties of applications such as watch a movie, play music and access internet. Many operating systems such as Windows, Mobile, IOS and Android are developed to give more functionality in mobiles. Android applications are currently being developed (Susilo, 2014). The most popular messenger applications among the college students are consisted WhatsApp (WA), Skype and GO SMS Pro (Jadhaw, Bhutkar, \& Mehta, 2013). Technologies such as WhatsApp messages have achieved increasing prevalence in societies. These kinds of messaging technologies are greatly applied among undergraduate learners nowadays (Lenhart, 2007).

Digital dialogues between members of students and trainers have become common during the past decade through different channels: SMS, Email, Facebook groups, Twitter and freshly WhatsApp. Every one of these tools has various attributes that affect suitability for learning goals (Calvo, Arbiol \& Iglesias, 2014). One of the most exciting issues about WhatsApp messaging and other general technologies (text messaging, video games, etc.) is that they are prospective acquisition tools (Dearstyne, 2011; Brown-Owens, Eason, \& Lader, 2003). Unlike the other forms of communication and any other technologies that occasionally do not work and students do not use after school hours, WhatsApp enables easy and quick transference of links to study materials. Sending homework materials through WhatsApp make sure that all students receive the message, whether it is a video specified for class or copy of an answer to an exercise sent outside the classroom hours (Bouhnik \& Deshen, 2014).

According to Yeboah \& Evur (2014) technology is growing at a very rapid percentage, and Whatsapp is one of the evolutions in technology that is ordinarily operated on particular mobile phones. As the smartphones became in demand, many messaging services were initiated but Whatsapp has become very widespread among them. Connection through mobile phones and particularly with Whatsapp messenger has become simpler, faster and cheaper. Whatsapp is employed in higher education. It is used for the improvement of exchange of views and participating data among lecturers and their pupils. Yalcinalp and gulbahar (2010) stated that the advantages of these implementations as follows: motivate learners to learn by predicting demands, make collaborative learning productive and beneficial, construct an association that encourages learner-to-learner for constant and ongoing learning.

While majority of educationalists acknowledge that WhatsApp messages are vastly worked by undergraduate learners, there sound to be one separate idea of its impact on student academy (Alsaleem, 2014; Atta M. S. Salem, 2013). There are individuals who consider the use of so-called "Internet English" not only as an example of how language is continuously progressing and shifting, but also as a kind of literacy, which can be developed to appoint learners in more customary learning. Now, people are really watching words on phone screens. According to Helderman (2003) and Linhart (2007), instant messaging and e-mail are a new generation of writers, accustomed to translating their views and feeling into words. They write more than any individual has since the days when telephone calls were limited (Alsaleem, 2014). Overall, according to Bere and Chipunza (2013) WhatsApp has turned into a shared platform which promotes accessibility, motivates cooperation and strengthens motivation to take a lively component in academic assignments.

\subsection{Importance of Vocabulary in Learning a Language}

The indispensable role of vocabulary learning in the realm of language learning for all four skills has been declared by many L2 educators (Taylor, 2005). Luo (1992, cited in Lessard-Clouston, 1996) mentioned the importance of vocabulary as "vocabulary-words, phrases, idioms, etc. are at the heart of all language usage in the skill areas of listening, speaking, reading, and writing, as well as culture" (p. 27). To communicating in a meaningful way, McCarthy (1990) stated that one needs to know a wide range of words to express a wider range of meanings. Showing the importance of vocabulary, Wilkins (1972, p. 111) asserted that "while without grammar very little can be conveyed, without vocabulary nothing can be conveyed". Therefore, being one of the important factors in promoting and preventing L2 learning process, having lexical repertoire is essential to understand articles, magazines, and other written texts. Also, handling written messages, listening texts, and conversation, the L2 learners need to have adequate words (Flynn, 2007). Moreover, regarding the importance of words in handling communication, Hatch (1983) confirmed that 
when one's knowledge of a new language is not adequate, adequate knowledge of lexicon probably makes the communication possible. Making a pertinent statement about the significance of vocabulary, Krashen (1989) mentioned that the L2 learners understand the importance of vocabulary for mastering the L2 as they carry dictionaries with them rather than grammatical references. Those L2 learners who benefit from a rich knowledge of vocabulary perform better in both receptive and productive skills more successfully than those whose repertoire is smaller.

\subsection{Concept of Collocations and its Significance in a Fluent English Language}

It is apparent that collocations are really worth the attention of linguists and language educators. But each researcher has approached collocations from a different perspective. So, there are different categories: some researchers (Abadi, 2003) have approached the problem of translating collocations in a purely linguistic description. Others (Abdulmoneim, 2005) have been much interested in contrastive and error analysis while the rest of researchers have investigated collocations' use and in some case its relation to proficiency in speaking and/or writing. Since researches about this subject are extensive, we are going to state only some examples from each category. To the lexicon of English, the word of collocation is relatively new. Collocations are defined as ordered word phrases which attach together and become apparent regularly in the usage of English (Ashouri; Arjmandi \& Rahimi, 2014). However, it is widely accepted that the word "collocation" was coined by Firth in 1957 when he said "you shall know a word by the company it keeps" (as cited in Palmer, 1981, p. 75-76). Firth uses the word collocation to refer to the association of words in the same context so that when you see a word you expect the presence of another. He adds that collocations of a given word are statements of the habitual or customary places of that word order but not in other contextual order and emphatically not in any grammatical order. The collocation of a word or a 'piece' is not to be regarded as mere juxtaposition; it is an order of mutual expectancy. He farther believes that collocations of a word help us to understand its meaning. Firth gives the example of dark that collocates with night "one of the meanings of night is its collectability with dark" (Palmer, 1981, p. 196). Here, the meaning of the word night is clarified through its collocation dark. Also, the word that needs clarification- here night, is called the node word, whereas the word that could be combined with it is called collocation.

Collocations are one of the hardest aspects of foreign and second language to acquire. There is no common agreement among linguists on what a collocation is, and for the notion of collocation, various definitions have been suggested. Lewis (1997) defines collocation as "the readily observable phenomenon whereby certain words co-occur in natural text with greater than random frequency" (p.8). In another definition collocation is "an expression consisting of two or more words that correspond to some conventional way of saying things" (Shokouhi \& Mirsalary, 2010). Lewis (2000) has prepared a practical and pedagogical perspective of collocation which is accepted from the point of view of learners. He proposed that "collocations are classes of words that students will not imagine to find together" (p.29). Hyland (2008) points to collocation learning that is a key factor in second language learning and it refers to multi-word expressions as a main component of fluent linguistic production. Hill (1999) claims "students with good ideas often lose marks since they do not know the four or five most essential collocations of a key word that is primary to what they are writing about" (p.5). Smith (2005) stated collocation should be included in the curriculum.

The importance of collocations is one of the challenging dimensions of vocabulary learning in both achieving general language proficiency and communicative competence (Guenette, 2007; Lewis, 2001; Nesselhauf, 2003; Noonan \& Duncan, 2005; Truscott, 2007). Pawly and Syder (1983) discuss that collocational knowledge, as the essence of language knowledge, is indispensable for language learners to produce fluent and appropriate language. Jaen (2007) explains that, "It is a vastly adopted opinion that collocations are very crucial segments of knowledge of second language learning and they are necessary to non-native speakers of English in order to speak or write precisely and fluently." Shin and Nation (2008) explained one of the factors as to why teachers and learners should be regarded collocations being that they enhance learner's language. Also Skrzypek (2009) indicates that the importance of collocation by declaring that one of the criterion for discriminating a word is being aware of words with which it keeps company. Richards and Renandya (2002) believe that collocations are an essential element of language proficiency. Both of the researchers assert that absence of an expansive repertoire of vocabularies and collocations equals to second language learners who are not able to access their own complete potential. One of the challenging facets of vocabulary development is according to collocations in which general language proficiency and communicative competence can be thoroughly justified (Guenette, 2007; Lewis, 2001; Nesselhauf, 2003; Noonan \& Duncan, 2005; Truscott, 2007). The importance of collocations and their problems for the L2 learner are cited below.

Since no piece of spoken or written text is not totally without of collocations; hence, they are of crucial importance to the second language learner of English. According to Hill (2000) who states "It is estimated more than $70 \%$ of individual's dialogues in speaking, hearing, reading or writing are to be found in several forms of fixed expressions"(p.53). Collocations allow the learners to think more quickly and communicate more efficiently. Learning collocations helps the learners generate language at a much quick rate; since collocations name complex opinions quickly without using all brain space to focus on the form of words (Radhi, 2013). Nattinger and Dearrico (1992) pointed out that "the prefabricated speech has both the advantage of more efficient retrieval and of permitting speakers and hearers to focus their consideration on the larger structure of the discourse, rather than keeping it direct narrowly on individual words as they are produced" (p.32). Moreover; knowledge of collocation affects the appropriateness of a word. For example, handsome and beautiful have similar meanings, it is not correct to attribute a beautiful man or a handsome woman. The other advantage of collocational repertoire is related to reading. Because students do not discriminate chunks, so it is difficult for them to read unseen texts. In addition, students without collocation knowledge force to build longer statements. Because they do not acquaint with the collocations which express themselves precisely 
what they want to say. A student who selects the best collocation will express himself clearly and not only convey a general meaning but also something quite precise (Radhi, 2013). In the following a review of three of the most common arguments stressing the importance of developing collocational knowledge of language learners is presented.

Collocations are found everywhere. Hill $(2000$, p.53) points out that, "Collocations are found in up to $70 \%$ of everything we say, hear, read or write" emphasizes the powerful patterning that survives in language and demonstrates that a word-by-word approach cannot be competent answer for meaning in a text. Nation (2001, p.321) declares that, "the strongest position is that language knowledge is collocational knowledge because the stored sequence of words are the bases of learning, knowledge and use." Furthermore, Woolard declared that, "collocation has emerged as an important category of lexical patterning and it is quickly becoming an established unit of description in language teaching courses and materials" (Woolard, 2000, p.28). Lin (2002) supported that while collocation instruction has impacts on students' English vocabulary development; it made students' progress in their producing collocations after receiving collocation instruction.

All of the following reports emerge to support the issue that collocations are organized in the mind in some way to enable more efficient language processing, for both language reception and language production. The Substantial psycholinguistic evidence supports that language is acquired faster and more efficiently when learned in 'chunks' such as set phrases or routines (Ellis, 2001, p.67). Hermann (2003), Zareva \& et al. (2005) believed that the knowledge of word has been known as a significant subject in language proficiency. Aitchison (1987, p.79) accepts there are strong and continuous links between words in the mind. Hunt and Beglar (2005) consider that the prime component of language comprehension and use is the lexicon. Nevertheless; recently its importance in different aspects of learning second language has been acknowledged. Gleason (1982, p.355) states that working on the second language acquisition indicates that the second language learners do not begin so much with generative systems as with chunks, prefabricated routines or unopened packages. According to Conklin and Schmitt who found that 'chunks have a processing advantage over creatively generated language' (Conklin \& Schmitt; 2008, p.72).

A third factor mentioned reinforcing the acquiring of collocation is that fluent and proper language use needs collocational familiarity. Pawley and Syder have studied that "Memorized clauses and clause-sequences form a high proportion of the fluent stretches of speech heard in everyday conversation... Speakers indicate a high rate of fluency while explaining familiar backgrounds or actions in recognized phrases... The normal building blocks of fluent spoken discourse include memorized sentences and phrases" (Pawley \& Syder, 1983, p.208). Towell, Hawkins and Bazergui (1996), in an enquiry of learners of French as a second language, found that increased fluency originated in learners storing memorized sequences. Sung (2003) in the USA explored a significant correlation between the knowledge of lexical collocation and the subjects' speaking proficiency. Moreover, Hsu and Chiu (2008) in an investigation of Taiwanese EFL learners did the same study. Hence, the three contexts summarized stressing the significance and importance of collocations in ESL/EFL classrooms. Believing that collocations are vital in learning a language of ESL/EFL learners, the instructors and their students need to regard how this might best be done.

But the prime reason for why many L2 learners cannot cope with collocations easily as Smadja (1989, cited in Wei, 1999) explained: "Many wording choices in English sentences cannot be accounted for semantic or syntactic grounds; they can only be expressed in terms of relations between words that usually occur together." Goebert (2007) explored that learners even if they have been trained words as chunks, prefer to utilize decontextualized vocabulary strategies to comprehend collocations. Goebert (2007) added that students tend to write first language equivalents of single words; so when students see the words in phrases, they cannot understand them. This surface level knowledge is a serious obstacle to meaningful learning and creates collocation-related problems. Carter (1998) states that the L2 learner is taught that amicable is a synonym of friendly but then the student is told that amicable divorce is accepted but friendly divorce is not. Moreover, second language learners make mistake s since of their mother-tongue interference. Also, the learners may overgeneralize the rates of collocations. For instance, they can think that put off your coat is the opposite of put on your coat, because they have learnt that turn on is the opposite of turn off. Hence, regarding the study was conducted by Koosha and Jafarpoor (2006) who confirmed that L1 has the negative influence on acquiring collocations by EFL learners (Farokh, 2012).

According to Carter and Mccarty (1988) collocations are beneficial not only for English comprehension but for English production. The two researchers asserted that, "collocations teach students expectations about which sorts of language can follow from what has preceded. Students will not have to go about reconstructing the language each time they want to say something but instead can use these collocations as pre-packaged building blocks" (Carter \& McCarthy, 1988, p.75). Benson et al. (1998) said that, "collocations are arbitrary and unpredictable" but despite the arbitrary nature of collocations, the other researchers recommended that teachers should motivate their pupils to acquire collocations. Furthermore, Woolard declared that, "collocation has emerged as an important category of lexical patterning and it is quickly becoming an established unit of description in language teaching courses and materials" (Woolard, 2000, p.28). Lin (2002) supported that while collocation instruction has impacts on students' English vocabulary development; it made students' progress in their producing collocations after receiving collocation instruction.

\subsection{Mobile-Based Learning versus Paper-Based Learning and Collocation Learning}

Certainly, there is a vast body of research devoted to effects of technology on second language acquisition; however, a small number of them related to the effects of cell-phone on SLA (Yousefzadeh, 2012). Wanger and Wilson (2005) stated that Mobile-learning can bridge formal and informal learning experiences. Accordingly, learning forms have changed from traditional classroom learning to electronic learning (E-learning), and mobile learning (M-learning) or 
ubiquitous learning (U-learning). Through these effective learning forms, mobile learning is beneficial and flexible; namely, mobile learning can overcome limitations of time and space, empowering learners to study whenever and wherever feasible (Chen \&Chung, 2007). While Cavus and Ibrahim (2009) declared that there is a rise use of wireless technologies in education all over the world. In fact, Wireless technologies such as laptops, computers and mobile phones are continually revolutionizing education and shifting the traditional classroom-based learning and teaching into anytime and anywhere education. Recently the principal language teaching/learning discussions are utilizing technology in second language teaching/learning. Similarly, the processes of language learning technologies nowadays have preferred to be mobilized, portable, and personalized. A mobile technology device must encounter three measures: it should be able of preparing communication and information acts, be tiny enough to be readily carried and be utilized, at least part of time, without a physical relationship to an established power source or telecommunications services. To the majority of individuals, mobile equals to portable and movable. The usage of mobile phone and the other movable devises are now beginning to have an effect on language teaching and learning all over the world.

It is comprehensively accepted view that collocations are very essential segment of knowledge of second language acquisition and they are crucial to nonnative speakers of English in order to write and speak correctly and fluently (Jaean, 2007 cited in Ozgul \& Abdulkadir, 2012). In vocabulary teaching there is a high significance of collocations and the relationship of collocation is essential in the study of vocabulary, and collocation is a fundamental organizing principle in the vocabulary of any language (McCarthy, 1990:12). Learners are rarely conscious of importance of collocation knowledge for their language learning. As Woolard (2000) stated that learning vocabulary easily equals learning the meaning of new words. Therefore, these researchers (Thornton \& Houser, 2005; Cavus \& Ibrahim, 2009; Li, 2009; Jalalifarahani \& Ghovehnodoushan, 2011) found that cell phone can be valuable means for advocating students learning. Mobile-based learning assists to personalize the language learning background. Mobile technologies prepare the learners with supports to associate their learning processes with real world experiments, develop new ways for meeting what is learnt in the classroom and what should be learnt outside the classroom looks unavoidable (Ketabi, Zarei \& Khazaie, 2011). Grace (1998) declared that the learners can learn after classroom, because of the class time restriction, thus; the essential responsibility of the student outside the classroom is vocabulary reinforcement. The learners can learn their own words in anyway and anytime. So, it is concluded that mobile phones play a main role in vocabulary and collocations. The teachers should be aware of the profits of technology, particularly cell phone in language learning.

\section{Methodology}

\subsection{Participants}

To pile up the required data, a sample of 60 Iranian EFL learners, aged 20 to 28, from Kimiya Institute located in Masjidsoleyman, Iran were selected. These participants were selected from 80 individuals who sat for the Oxford Placement Test (OPT). Sixty learners received the required score in OPT. Regarding their educational background; the majority of the participants had university degree, B.A. in majors other than English from state or Azad universities all around Iran. Furthermore, a few of the learners were not students at college. They had no certification of college. They had studied in high school and had diploma. All the selected individuals were native speakers of Persian and their level of English language proficiency was intermediate. The participants were divided into two groups: experimental and control groups. In addition, 15 learners took part in the pilot-testing of the instruments. They were also native speakers of Persian and their level of English language proficiency was intermediate. They had been selected based on their performance on Oxford Placement Test (OPT).

\subsection{Instruments}

The participants in this study were given the following tests for data collection. All of the selected learners participated in the following examinations.

\subsubsection{Oxford Placement Test (OPT)}

For conducting this research, the researcher needed an OPT which is a standard examination, to determine the level of the students. The whole population in the present examination was $80 \mathrm{EFL}$ learners. Then, the individuals whose scores were 70 and higher were chosen. The selected learners were regarded as the sample for experimental and control groups.

The OPT was carried out to participants studying English as a foreign language in a language institute. The OPT consisted of 60 items, including 10 multiple-choice and true-false reading, 10 writing, and 40 multiple-choice language use items. The time limit for answering the test was 65 minutes. This study used all parts of the OPT to select a group of intermediate level L2 students and to figure out L2 reading proficiency level of the students.

Therefore, the participants answered the structure, vocabulary, writing and reading comprehension segments of the test. After administrating the test, the received results were evaluated based on the OPT associated rating levels chart and those who obtained 70 or more in this test were judged as intermediate learners.

\subsubsection{Pretest and Posttest}

The participants in this study were given two tests. Then a 30-item collocation test was given to the learners before and after the treatments of study as pretest and posttest. This test was syllabus-based and was used to measure the learners' collocation knowledge. It consisted of multiple choice items, fill in the blank, matching and completion. 
In order to check the reliability of the collocation pretest, which had been designed by the researcher, the test was pilot studied on 15 learners of the same age and proficiency level. The participants in pilot testing took part in the pretest separately. An experimental research design was employed by the researcher. The data collection procedure was carried out in a language institute. The first step of this study was the administration of OPT. The OPT was administrated to a group of learners $(\mathrm{N}=80)$ in order to choose intermediate EFL learners. The majority of the participants had university degree or they were students at college. Based on the OPT associated rating levels chart, the participants whose scores were 70 or more were regarded as the sample of the investigation. The selected individuals were divided into two groups: experimental and control. The selected participants in two groups took the pretest in order to evaluate their collocation knowledge. Accordingly, both the experimental and control groups participated in the examination. The level of the two groups is evaluated by the same analysis.

\subsection{Procedure}

An experimental research design was employed by the researcher. The data collection procedure was carried out in a language institute. The first step of this study was the administration of OPT. The OPT was administrated to a group of learners $(\mathrm{N}=80)$ in order to choose intermediate EFL learners. The majority of the participants had university degree or they were students at college. Based on the OPT associated rating levels chart, the participants whose scores were 70 or more were regarded as the sample of the investigation. The selected individuals were divided into two groups: experimental and control. The selected participants in two groups took the pretest in order to evaluate their collocation knowledge. Accordingly, both the experimental and control groups participated in the examination. The level of the two groups is evaluated by the same analysis.

The participants in experimental group installed WhatsApp on their cell phones or tablets. The participants in the experimental and control groups were taught the course book Vocabulary in Use Basic (10 units) inside the classroom. Both groups repeated, practiced, and did the exercises in the book separately. Then, the experimental group used WhatsApp in order to practice and repeat the selected and taught collocations with native and non-native English speakers around the world outside of the L2 classroom. The participants in the experimental group were asked to keep the thread of their conversation by using Whatsapp application. Moreover, they were asked to report their progress after each session. They reported their progress through brief evaluation of collocation knowledge. The participants in the control group received collocation instruction through the conventional method which was popular in their courses. Therefore, the control group had no instrument for learning collocations. By the end of the course, the posttest was run to compare the differences in vocabulary learning improvement of two groups of participants which was run in 30 minutes.

\subsection{Data Analysis}

After the essential data were collected, the Statistical Package for Social Sciences (SPSS, 20) was used in order to run required statistical tests. The researcher ran independent sample $t$ tests in order to verify the hypothesis. In addition, descriptive statistics (such as mean, standard deviation, kurtosis, skewness and frequency) were used to show the general information of obtained scores.

\section{Results and Discussions}

\subsection{Results}

In order to assess the effects of training among the groups of learners, the performance of the participants in experimental and control groups were to be compared to make sure that they were homogeneous at the beginning of the treatment. To this end, an OPT was administered and those participants who obtained a score of 70 or more were chosen as the participants of the study $(\mathrm{N}=60)$. What follow is the detailed results gained in this study.

Table 1. Descriptive Statistics for the Mean Comparison of the OPT between QEG and CG.

\begin{tabular}{|c|c|c|c|c|c|}
\hline & Groups & $\mathrm{N}$ & Mean & Std. Deviation & Std. Error Mean \\
\hline \multirow[t]{2}{*}{ Scores } & Experimental & 30 & 48.44 & 5.18 & 0.99 \\
\hline & Control & 30 & 48.84 & 3.58 & 0.70 \\
\hline
\end{tabular}

As it is shown in Table 1, there is no statistically significant difference between the mean scores of QEG and CG groups (the mean score for experimental group is 48.44 and that for control group is 48.84 that is a difference of 0.40 which is not a significant difference). In order to be more objective regarding the claim of homogeneity of the two groups, an independent sample t-test was run between the scores of OPT of control and experimental groups, the results of which are presented in Table 2. As it is shown in this table, the t-observed is -0.32 which is lower than the $t$-critical from the table of t-scores, so it can safely be claimed that the two groups are homogeneous in terms of their proficiency level. As a result, the study went on safely with these two groups. 
Table 2. Results of the Independent Sample t- Test of the OPT between QEG and CG.

\begin{tabular}{|c|c|c|c|c|}
\hline $\begin{array}{l}\text { Levene's Test for } \\
\text { Equality of } \\
\text { Variances }\end{array}$ & $\mathrm{t}$-test for $\mathrm{Ec}$ & ity of Means & & \\
\hline Sig. & $\mathrm{df}$ & $\begin{array}{ll}\text { Sig. (2- } & \text { Mean } \\
\text { tailed) } & \text { Difference }\end{array}$ & $\begin{array}{l}\text { Std. Error } \\
\text { Difference }\end{array}$ & $\begin{array}{l}\text { 95\% Confidence } \\
\text { Interval of the } \\
\text { Difference }\end{array}$ \\
\hline
\end{tabular}

Lower Upper

$\begin{array}{llllllllll}\begin{array}{l}\text { Equal } \\ \text { variances } \\ \text { assumed }\end{array} & 4.36 & 0.042 & -0.32 & 51 & 0.74 & -0.40 & 1.22 & -2.86 & 2.06 \\ \begin{array}{l}\text { Equal } \\ \text { variances not } \\ \text { assumed }\end{array} & & & & & & & & & \\ \end{array}$

The hypothesis of the present study which was formulated based on the research statement that was 'Using WhatsApp does not have significant effects on improving Iranian EFL learners' collocation knowledge.' Therefore, the following steps were taken in order to test the hypothesis and find the answer for the question of the study.

The scores on the pretest were first analyzed and tabulated in Table 3. Accordingly, the pretest was considered from two different perspectives; first in order to serve the research question as an indicator for making sure that both groups were starting from the same level; second, it was used for measuring the amount of knowledge gaining after the treatment.

Table 3. Descriptive Statistics for the Mean Comparison of the Collocation pretest between Experimental and Control Groups

\begin{tabular}{cccccc}
\hline \multirow{3}{*}{ Pretest scores } & Groups & $\mathrm{N}$ & Mean & Std. Deviation & Std. Error Mean \\
\cline { 2 - 6 } & Experimental group & 30 & 14.43 & 4.60 & 0.84 \\
& Control group & 30 & 16.10 & 7.20 & 1.31 \\
\hline
\end{tabular}

According to the statistics depicted in Table 3, the mean difference of pretest for the two groups is 2.33 (the mean for control group being 16.10 and for experimental group 14.43) which is not statistically significant. This could mean that all of the participants' knowledge of collocation at the onset of the study was nearly the same, so any change in their behavior could be attributed to the treatment used in the study.

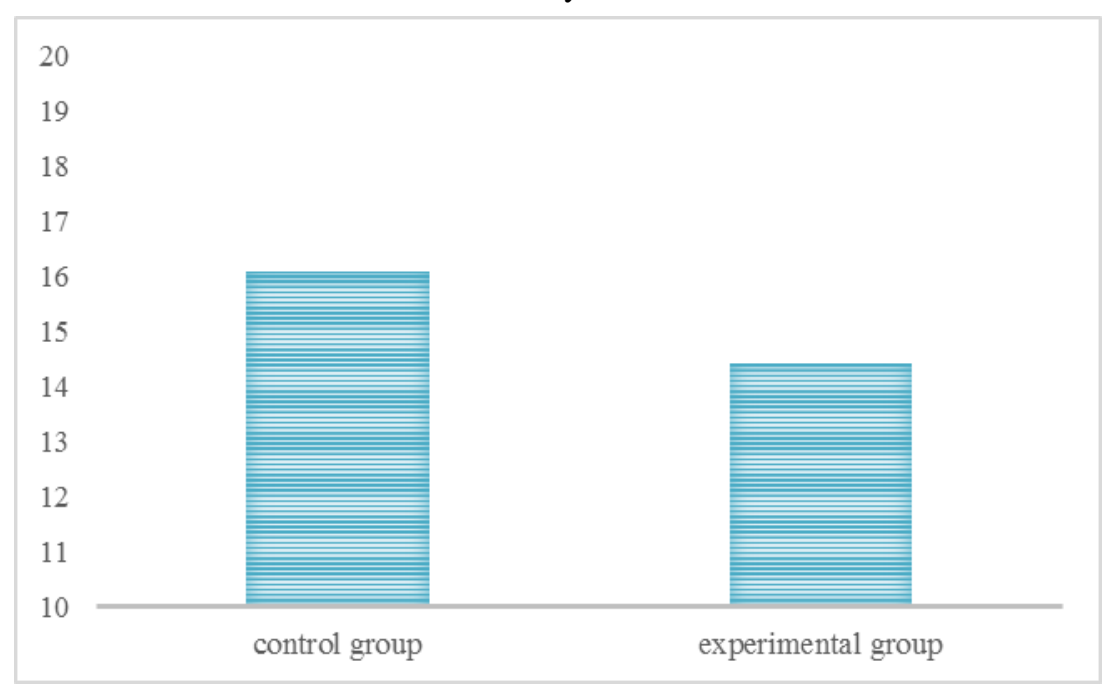

Figure 1. The Difference between Pretests of Control Group and Experimental Group Score Means 
As it is clearly shown in Figures 1, the pretest mean for experimental group is 14.43 which are higher than that of control group, being 16.10 having a mean difference of 2.33 . So it can safely be claimed that the two groups were homogeneous in terms of their collocation knowledge. Even though the difference of the two groups seems not to be significant regarding the descriptive statistics, the item at hand needs more exact clarification. To this end, an independent samples t-test was run between the pretest scores of the two groups, the results of which are presented in Table 4.

Table 4. Results of the Independent Samples t- test between Posttest Scores of Experimental and Control Groups

\begin{tabular}{|c|c|c|c|c|c|c|c|c|c|c|}
\hline & & $\begin{array}{l}\text { Levene } \\
\text { for Equ } \\
\text { Varianc }\end{array}$ & $\begin{array}{l}\text { s Test } \\
\text { ality of } \\
\text { es }\end{array}$ & t-test & Equali & ty of Me & ans & & & \\
\hline \multirow{4}{*}{ Pretest scores } & & \multirow[b]{2}{*}{$\mathrm{F}$} & \multirow[b]{2}{*}{ Sig. } & \multirow[b]{2}{*}{$\mathrm{t}$} & \multirow[b]{2}{*}{ df } & \multirow{2}{*}{$\begin{array}{l}\text { Sig. } \\
(2- \\
\text { tailed })\end{array}$} & \multirow{2}{*}{$\begin{array}{l}\text { Mean } \\
\text { Difference }\end{array}$} & \multirow{2}{*}{$\begin{array}{l}\text { Std. Error } \\
\text { Difference }\end{array}$} & \multicolumn{2}{|c|}{$\begin{array}{l}95 \% \text { Confidence } \\
\text { Interval of the } \\
\text { Difference }\end{array}$} \\
\hline & & & & & & & & & Lower & Upper \\
\hline & $\begin{array}{l}\text { Equal } \\
\text { variances } \\
\text { assumed }\end{array}$ & 10.998 & 0.002 & -1.06 & 58 & 0.29 & -1.66 & 1.56 & -4.79 & 1.45 \\
\hline & $\begin{array}{l}\text { Equal } \\
\text { variances } \\
\text { not } \\
\text { assumed }\end{array}$ & & & -1.06 & 49.32 & 0.29 & -1.66 & 1.56 & -4.80 & 1.46 \\
\hline
\end{tabular}

Based on the results given in Table 4, the level of significance is 0.29 which is higher than the identified level of significance $(0.29>0.05)$. This way it could be concluded that there was no significant difference between the performance of experimental and control groups at the beginning of the study. In order to find out the possible effects of using WhatsApp on collocation learning of EFL learners, the participants in experimental group were exposed to training on collocation via WhatsApp. After the treatment was conducted, the participants sat for a collocation posttest, and then the results were compared. The following section is devoted to an analysis of the obtained results from the posttest.

Table 5. Descriptive Statistics for the Mean Comparison of the Collocation posttest between Experimental \& Control Groups

\begin{tabular}{llllll}
\hline & Groups & N & Mean & Std. Deviation & Std. Error Mean \\
\cline { 2 - 5 } Post test scores & experimental group & 30 & 19.30 & 5.97 & 1.09 \\
& control group & 30 & 16.60 & 3.67 & 0.67 \\
\hline
\end{tabular}

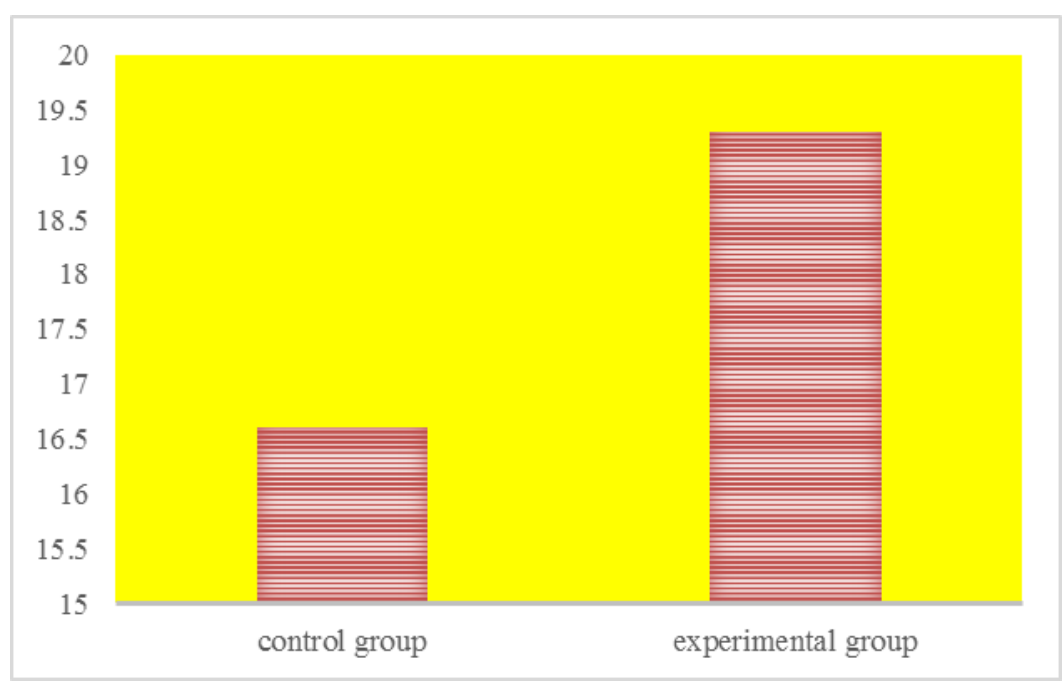

Figure 2. The Difference between Posttests of Experimental and Control Group, Score Means 
In order to ascertain that the mean difference between the posttests of experimental and control groups is significant, an independent sample t-test was run between the posttest scores. Table 6 illustrates the results of this t-test.

Table 6. Results of the Independent Samples t- test between Posttests Scores of Experimental and Control Groups

Levene's Test for

Equalitylof

Variances t-test for Equality of Means

$95 \%$ Confidence

Interval of the

Difference

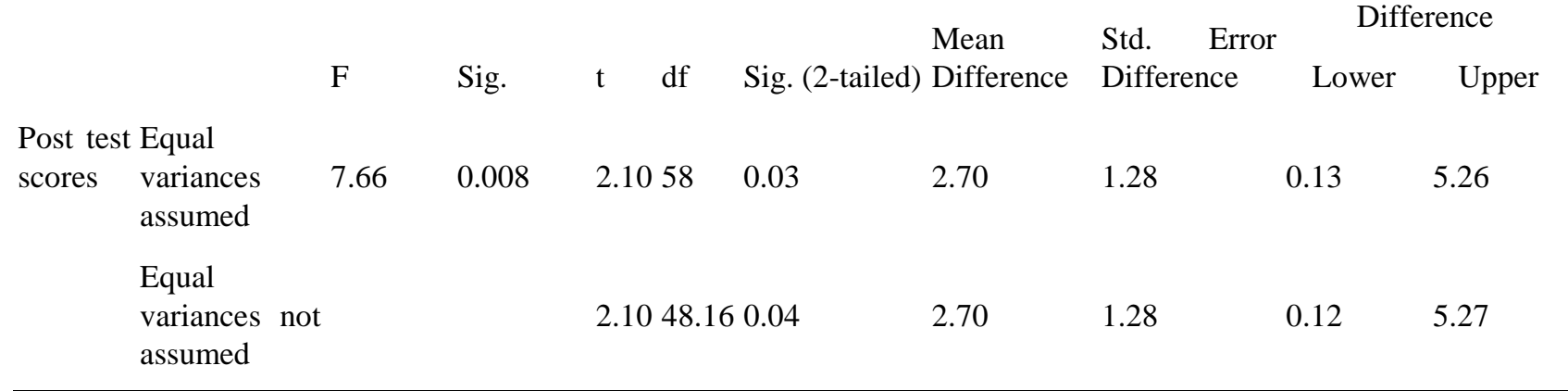

The significance level in Table 6 is 0.03 which is smaller than the identified level of significance $0.05(0.03<0.05)$. This expresses the fact that the difference between the performance of the experimental and control groups is statistically significant. This leads to the rejection of the null hypothesis of the research. Differently stated, Whatsapp turned out to be positive in assisting language learners with gaining new collocations well.

In principle, it is strongly agreed that WhatsApp has both technological and pedagogical platforms that proposes a greater focus on the learner; besides, it plays a key role as a facilitator of the learning process outside the restricted walls of the EFL instructional contexts and classrooms. Obviously, learning a new language through WhatsApp can reinforce and develop numerous opportunities for flexible learning and set a helpful foundation for enlarged selfdirected learning. The findings of this study provided some insights into the utilization of WhatsApp application in learning a second language. Overall, the present study focused on investigating the potential relationship between utilizing a widespread ICT tool such as mobile application, namely, WhatsApp on Iranian intermediate EFL learners' collocation knowledge.

\subsection{Discussions}

In fact, the study at hand declared that WhatsApp as an ICT tool influences learner's vocabulary knowledge particularly collocation lexicons enhance when using WhatsApp application. ICT tools such as MALL for learners of second language are flexible establishments that can be developed and refreshed based on user's requirements. As a result, in the occurring research, the experimental groups outperformed the control group in posttest of collocation test. The results in tables and figures revealed that there was a significant difference between the experimental and control groups, based on the collocation knowledge of two groups. The findings according to the tables and figures expressed the fact that the differences between the performance of the experimental and control groups were statistically significant. This conclusion led to the rejection of the first null hypothesis of the research. Differently stated, WhatsApp turned out to be positive in assisting language learners with gaining new collocations well.

The findings related to the null hypothesis seemed to be compatible with the views of researchers who argued for the effectiveness of Electronic Dictionary on English collocation learning of EFL learners and in the other study that was on the impact of the mentioned means on collocation learning and retention of Iranian EFL learners (Murnani \& Salehi, 2015). Moreover, the findings of this study were in line with those of Yunus, Salehi, and Amini, (2015) who claimed that CALL integration in EFL contexts has intensified remarkably in modern and advanced years. More apparently, this study discussed the effect of using CALL on vocabulary acquisition and attempted to explore for efficient methods to integrate CALL in vocabulary acquisition. On the other hand, the results of data analysis supported Salehi and Habibi (2015) who have corroborated the efficiency of EFL learner's attitudes towards using thesaurus part of Microsoft Word in vocabulary acquisition and impact of utility of this software on EFL learner's vocabulary knowledge (Salehi \& Habibi, 2015; Atta M. S. Salem, 2013).

In addition, the findings of the present study advocated Bouhnik and Deshen (2014) who claimed that WhatsApp can be viewed as a social network that enable individuals to access a plenty of information rapidly. In fact, one of the unique applications is the feature that creates a group to communicate within its boundaries. Technically, the purpose of their study was in accordance with the present study that explored classroom communication between intermediate students using WhatsApp. Furthermore, the conclusions of this study more support the discoveries of the other researchers who have verified the significance of Internet-based tools for English learning (Alsaleem, 2013; Susilo, 2014). On the other hand, the findings are especially in line with those of Alavinia and Quitassi (2013) who supported mobile phone as a learning tool that can be one of the multiple novel and stimulating ways of struggling with learners' needs. To sum up, 
learners via different applications such as WA as an instructional device could share their information, talk over group assignments as well as they evaluate each other's work.

\section{Conclusions and Implications}

In fact, in the modern and advanced age, cell phones are influential and substantial means of communication to the most of individuals. More recently, Yeung (2013) declared that social technologies such as WA and Viber go around language learning and communication. In particular, WhatsApp as one of the messaging applications has become popular among learners in various classroom settings that have allowed them to communicate with others in their contact list through text. Such great possibilities of WhatsApp tool have turned it into a magic resource for teaching lexicons of a second language to L2 learners. Accordingly, this study was an attempt to shed light on the reality if whether using WhatsApp as a mobile application could have any influence on the acquisition of collocations repertoire of Iranian EFL learners. The key findings of the present study were briefly mentioned below.

Wholly, the current study probably protested accurately which learning via mobile is an influential strategy that has the ability of helping learners of a second language. One of the pedagogical conclusions of the study was to raise the view of learners in learning a second language via MALL. Therefore, it is beneficial to all EFL learners to apply their mobile phones technically and perfectly for learning second language. The suitability and speed of utilizing WhatsApp made the finer opportunity for students to communicate with their teacher as well as the other peers simply and greater exposure to new collocations. After conducting different analyses, it was made clear that traditional learning and acquisition collocations through WhatsApp were not the same in learning since the group that received instruction via WhatsApp outperformed the other group that received traditional learning.

The findings of this study declared that technology and education are closely related to each other in the information era and consequently technology has the potential ability to make learning easier and more exiting. Therefore, significance and implication of technology in learning a second language has been clarified. In fact, technology can permit learners of a second language to be connected to each other. When learners utilized digital tools to be connected, they were able to internalize content in order to learn. This connection and exchange of information can help learners develop the capability to create new knowledge at any point in time. The rapid progress of technology affected many changes both in knowledge generally and learning a language particularly. One of the marvelous transformation of learning acknowledged that learning is no individual activity, but rather a process that allowed the students to flourish in the digital era.

According to the present study, WhatsApp as a learning platform used the groups in order to improve the accessibility of learning materials and the performance of learning activities. Consequently, four main factors that motivated the researcher for the creation of a WhatsApp group are mentioned in the following:

- By establishing a WhatsApp group, the students could communicate with their teacher and classmates, transmit data, and assist learners to feel freshly.

- The researcher groomed a positive social atmosphere in order to build a feeling of belonging and community through WhatsApp groups.

- The students were able to share information when started to help each other's questions. By creating a dialogue, the students worked as a team.

- The WhatsApp teams apply the learning platform in order to increase the accessibility of learning materials and activities.

Furthermore, the study in hand aimed at investigating the key function of using MALL in EFL classes. The present study evaluated a combination of technology and language practice in acquisition of collocations of a second language. According to the findings of the study, Iranian EFL learners can discriminate the attributes and uses of MALL in learning a second language and apply its advantages and implications appropriately to their learning. On the other hand, this study suggested that an advancement of collocation knowledge through using MALL can guarantee the vocabulary repertoire of learners.

Using mobile-based applications such as WhatsApp is not very popular and appropriate among EFL teachers and students in Iran because they have not been trained enough how to employ these applications in the learning process. In spite of the available views, it is also hoped that the findings of this study and similar investigations can motivate EFL learners to benefit from such useful tools to boost their second language learning. Finally, EFL materials developers and syllabus designers should consider integrating ICT tools such as MALL in their materials. In fact, they are suggested to transform their perspective of such instruments as a platform of learning. They are also recommended to involve various exercises, activities, and tasks in the Internet-based tools.

\subsection{Suggestions for Future Research}

The present investigation owns the potential studies that can offer definite suggestions for further research in future. In what follows, several suggestions may be made from this research for forthcoming research enquiries:

1. It seems necessary that future investigations are needed to explore the significance of collocations acquisition for Iranian EFL learners. Hence, the practitioners and the teachers should pay double attention to teaching collocation and attempt to extract the learner's consideration to learning them and assist students to learn them more efficiently. 
2. In order to have a more comprehensive understanding of the impact and use of mobile learning tools out of school works, future investigations should take into account the effective use of mobile devices on student school work especially outside the classrooms.

3. The current study can serve as a confirmation of the advantages of new chat applications in smart phones as learning tools. Eventually, based on the present study and previous findings in mobile learning, the effect of WhatsApp on improving collocations was recommended. In fact, there are plenty of chat applications in smart phones by which the learners can improve learning a second language.

4. It remains to be investigated similar studies may be performed with the other proficiency levels. It is supposed that learners at both lower and upper levels can profit mobile device in learning a second language differently.

\section{References}

Abdulmoneim, M. (2005). Interlingual Transfer of Idioms by Arab Learners of English. The Internet TESL Journal, VIII (12), 22-29.

Aitchison, J., \& Gilchrist, A. (1987). Thesaurus construction: a practical manual.

Alavinia, P., \& Qoitassi, K. (2013). On the Viability of Vocabulary Learning Enhancement through the Implementation of MALL: The Case of Iranian EFL Learners. Journal of Language Teaching and Research, 4(2), 412-426.

Alsaleem, B. I. A. (2013). The effect of "Whatsapp" electronic dialogue journaling on improving writing Vocabulary Word Choice and Voice of EFL Undergraduate Saudi Students. Arab World English Journal, 4(3), 213-225.

Ashouri, S., Arjmandi, M., \& Rahimi, R. (2014). The Impact of Corpus-Based Collocation Instruction on Iranian EFL Learners' Collocation Learning. Universal Journal of Educational Research, 2(6), 470-479.

Atta M. S. Salem, A. (2013). The impact of Technology (BBM and WhatsApp Applications) on English Linguistics in Kuwait. International Journal Of Applied Linguistics And English Literature, 2(4), 65-69.

Attewell, J. (2005). From research and development to mobile learning: Tools for education and training providers and their learners. In 4th World Conference mLearning on (pp. 1-6).

Bouhnik, D., \& Deshen, M. (2014). WhatsApp goes to school: Mobile instant messaging between teachers and students. Journal of Information Technology Education: Research, 13, 217-231.

Brown-Owens, A., Eason, M., \& Lader, A. (2003). what effect computer method communication, specifically instant messages, have on 8th grade writing competencies.

Calvo, R., Arbiol, A., \& Iglesias, A. (2014). Are all Chats suitable for learning purposes? A study of the required characteristics. Procedia Computer Science, 27, 251-260.

Cárter, R., \& McCarthy, M. (1988). Vocabulary and Vocabulary Teaching. Harlow-Londres, Longman.

Carter, R. (1998). Vocabulary: Applied linguistic perspectives. London, UK: Routledge.

Cavus, N., \& Ibrahim, D. (2009). m-Learning: An experiment in using SMS to support learning new English language words. British Journal of Educational Technology, 40(1), 78-91.

Chan, T., \& Liou, H.-C. (2005). Effects of web-based concordancing instruction on EFL students' learning of verb-noun collocations. Computer Assisted Language Learning, 18(3), 231-251.

Chen, C.-M., \& Chung, C.-J. (2008). Personalized mobile English vocabulary learning system based on item response theory and learning memory cycle. Computers \& Education, 51(2), 624-645.

Chipunza, P. R. C. (2013). Using mobile devices to leverage student access to collaboratively-generated resources: A case of WhatsApp instant messaging at a South African University. In International Conference on Advanced Information and Communication Technology for Education ICAICTE.

Chowdhury, A., Breznik, G., Verdnik, K., \& Prihavec, B. (2012). Customer identification and authentication procedure for online internet payments using mobile phone. Google Patents.

Conklin, K., \& Schmitt, N. (2008). Formulaic sequences: Are they processed more quickly than nonformulaic language by native and nonnative speakers? Applied Linguistics, 29(1), 72-89.

Crescente, M. L., \& Lee, D. (2011). Critical issues of m-learning: design models, adoption processes, and future trends. Journal of the Chinese Institute of Industrial Engineers, 28(2), 111-123.

Crompton, H. (2013). A historical overview of mobile learning: Toward learner-centered education. Handbook of Mobile Learning, 3-14.

Dearstyne, B. W. (2010). A New Blueprint for Success. Information Management Journal, 44(5), 42-46.

Durrant, P., \& Schmitt, N. (2009). To what extent do native and non-native writers make use of collocations? IRALInternational Review of Applied Linguistics in Language Teaching, 47(2), 157-177.

Duus Henriksen, T. (2009). A little more conversation, a little less action, please: rethinking learninggames for the organisation. Aarhus UniversitetAarhus University, ArtsArts, Institut for Uddannelse og P\{æ\}dagogik (DPU) Department of Education, Institut for Uddannelse og P\{æ\}dagogik (DPU)-DidaktikDepartment of EducationCurriculum Research.

Echeverría, A., Nussbaum, M., Calderón, J. F., Bravo, C., Infante, C., \& Vásquez, A. (2011). Face-to-face collaborative learning supported by mobile phones. Interactive Learning Environments, 19(4), 351-363. 
Ellis, N. C. (2001). Memory for language. na.

Farrokh, P. (2012). Raising awareness of collocation in ESL/EFL classrooms. Journal of Studies in Education, 2(3), 55-74.

Firth, J. R. (1957). Papers in Linguistics, 0xford: Oxford University Press.

Flynn, J. R. (2007). What is intelligence? Beyond the Flynn effect. NewYork, NY: Cambridge University Press.

Garrett, N. (1991). Technology in the service of language learning: Trends and issues. The Modern Language Journal, 75(1), 74-101.

Gillingham, M. G., \& Topper, A. (1999). Technology in teacher preparation: Preparing teachers for the future. Journal of Technology and Teacher Education, 7(4), 303-322.

Gleason, J. B. (1982). Converging evidence for linguistic theory from the study of aphasia and child language. Exceptional Language and Linguistics, 347-356.

Gobert, M. (2007). Collocational knowledge of Gulf Arab students. Teaching and Learning Vocabulary in Another Language, 49-66.

Goldfarb, A., Pregibon, N., Shrem, J., \& Zyko, E. (2011). Informational brief on social networking in education. Emerging Teaching \& Learning Technologies Initiative, New York Comprehensive Center, Retrieved April, $26,2013$.

Grace, C. A. (1998). Retention of Word Meanings Inferred from Context and Sentence-Level Translations: Implications for the Design of Beginning-Level CALL Software. The Modern Language Journal, 82(4), 533-544.

Guénette, D. (2007). Is feedback pedagogically correct?: Research design issues in studies of feedback on writing. Journal of Second Language Writing, 16(1), 40-53.

Hartley, K., \& Bendixen, L. D. (2001). Educational research in the Internet age: Examining the role of individual characteristics. Educational Researcher, 30(9), 22-26.

Hassan Abadi, S. (2003). A Study of the Learning of English Lexical and Grammatical Collocations by Iranian EFL Learners. C.R.C.I.S. 45-59. http://www.sid.ir/En/VEWSSID/J_pdf/874200318703.pdf

Hatch, E. M. (1983). Psycholinguistics: a second language perspective. Rowley, MA: Newbury House.

Helderman, R. S. (2003). Click by click, teens polish writing; instant messaging teaches more than TTYL and ROFL. The Washington Post, 20.

Hermann, F. (2003). Differential effects of reading and memorization of paired associates on vocabulary acquisition in adult learners of English as a second language. TESL-EJ, 7(1), 1-16.

Hill, J. (1999). Collocational competence. Readings in Methodology, 162.

Hill, J. (2000). Revising priorities: From grammatical failure to collocational success. Teaching Collocation: Further Development in the Lexical Approach, 47-69.

Hsu, J., \& Chiu, C. Y. (2008). Lexical collocations and their relation to speaking proficiency of college EFL learners in Taiwan. Asian EFL Journal, 10(1), 181-204.

Hunt, A., \& Beglar, D. (2005). A framework for developing EFL reading vocabulary. Reading in a Foreign Language, $17(1), 23$.

Jadhav, D., Bhutkar, G., \& Mehta, V. (2013). Usability evaluation of messenger applications for Android phones using cognitive walkthrough. In Proceedings of the 11th Asia Pacific Conference on Computer Human Interaction (pp. 9-18).

Jaén, M. M. (2009). A corpus-driven design of a test for assessing the ESL collocational competence of university students. International Journal of English Studies, 7(2), 127-148.

Jalalifarhani, M., \& GHovehnodoushan, M. (2011). Mall and vocabulary learning in Elementary students. 2011 international conference on languages, literature and linguistics. IPEDR vol.20 IACSIT Press, Singapore

Kahari, L. (2013). The effects of Cell phone use on the study habits of University of Zimbabwe First Year Faculty of Arts students. International Journal of Education and Research, 10, 1-12.

Kajornboon, A. B. (2013). The effect of using social networking assisted interaction between peer and teacher in English language learning. In Proceedings from FLLT Conference, March 15 (Vol. 16).

Kaplan, A. M., \& Haenlein, M. (2010). Users of the world, unite! The challenges and opportunities of Social Media. Business Horizons, 53(1), 59-68.

Ketabi, S., Zarei, GH. R., \& Khazaie, S. (2011). Mobile mediated versus traditional method of L2 vocabulary learning: A comparison between vocabulary learning with and without pictorial annotation. International conference on language, literature and linguistics. IPEDR (26). IACSIT Press, Singapore.

Kindberg, T., Spasojevic, M., Fleck, R., \& Sellen, A. (2005). I saw this and thought of you: some social uses of camera phones. In CHI'05 extended abstracts on Human factors in computing systems (pp. 1545-1548).

Koosha, M., \& Jafarpour, A. A. (2006). Data-driven learning and teaching collocation of prepositions: The case of Iranian EFL adult learners. Asian EFL Journal, 8(4), 192-209.

Krashen, S. (1989). We acquire vocabulary and spelling by reading: Additional evidence for the input hypothesis. The Modern Language Journal, 73(4), 440-464. 
Lenhart, A., Madden, M., Smith, A., \& Macgill, A. R. (2009). Teens and social media: An overview. Washington, DC: Pew Internet and American Life.

Lessard-Clouston, M. (1996a). ESL vocabulary learning in a TOEFL preparation class: A case study. Canadian Modern Language Review, 53, 97-119.

Lewis, M. (1997). 13 Pedagogical implications of the lexical approach. Second Language Vocabulary Acquisition: A Rationale for Pedagogy, 255.

Lewis, M., \& Conzett, J. (2000). Teaching collocation: Further developments in the lexical approach. Language Teaching Publications Hove.

Lewis, M. (2001). Teaching Collocation: Further developments in the lexical approach. Hove, England: ThompsonHeinle publications.

Li, C. (2009). SMS-based vocabulary learning for ESL students. Unpublished master thesis, Auckland University of Technology, New Zealand. Loucky.

Lin, Y. P. (2002). The effects of collocation instruction on English vocabulary development of junior high school students in Taiwan. Unpublished Master Thesis, National Kaohsiung Normal University, Kaohsiung, Taiwan.

McCarthy, M. (1990). Vocabulary. Oxford: Oxford University Press.

McNeal, T., \& van't Hooft, M. (2006). Anywhere anytime: Using mobile phones for learning. The Journal of the Research Center for Educational Technology, 2 (2).

Mirsalari, G.-A., \& Shokouhi, H. (2010). Collocational Knowledge versus General Linguistic Knowledge among Iranian EFL Learners. The Electronic Journal for English as a Second Language, 13(4).

Murnani, Z. T., \& Salehi, H. (2015). Effect of Electronic Dictionary as an ICT Tool on English Collocation Learning of EFL Learners. Asian Journal of Education and E-Learning (ISSN: 2321--2454), 3(05).

Nation, I. S. P. (2001). Learning vocabulary in another language. Ernst Klett Sprachen.

Nattinger, J. R., \& DeCarrico, J. S. (1992). Lexical phrases and language teaching. Oxford University Press.

Nesselhauf, N. (2003). The use of collocations by advanced learners of English and some implications for teaching. Applied Linguistics, 24(2), 223-242.

Noonan, B., \& Duncan, C. R. (2005). Peer and self-assessment in high schools. Practical Assessment, Research and Evaluation, 10(17), 1-8.

Oladipupo, O., Daramola, O., Oyelade, J., \& Afolabi, I. (2015). Improving Rural Healthcare Delivery in Nigeria using Distributed Expert System Technology. In European Conference on e-Government (p. 501).

Ozgula, B. \& Abdulkadir, C. (2012). Teaching vocabulary through collocations in EFL classes: The case of Turkey. $1(1), 21-32$.

Palmer, F. R. (1981). Semantics. Cambridge University Press. Retrieved from https://books.google.com/books?id=UWJSaxH9GiMC

Pawley, A., \& Syder, F. H. (1983). Two puzzles for linguistic theory: Nativelike selection and nativelike fluency. Language and Communication, 191, 225.

Prensky, M., \& Berry, B. D. (2001). Do they really think differently. On the Horizon, 9(6), 1-9.

Radhi, A. H. J. (2013). Collocations and the Practice of TESOL. Int. J. Bilin. Mult. Teach. Eng, 1(2), 49-54.

Richards, W., \& Renandya, A. (2002). Methodology in language teaching: An anthology of current practice. 157272.New York: Cambridge University Press.

Salehi, H., \& Habibi, S. B. (2015). EFL Learners' Attitudes towards Using Thesaurus Part of Microsoft Word in Vocabulary Acquisition. In 1 st International Conference on Teaching \& Learning (ICTL) (Vol. 14, p. 61).

Salehi, H., \& Salehi, Z. (2012a). Challenges for Using ICT in Education: Teachers' Insights. International Journal of EEducation, E-Business, E-Management and E-Learning, 2(1), 40-43.

Salehi, H., \& Salehi, Z. (2012b). Do high-stakes tests facilitate or hinder the use of ICT in the classroom? In $3 r d$ International Conference on e-Education, e-Business, e-Management and e-Learning. Singapore.

Salehi, H., \& Salehi, Z. (2012c). Integration of ICT in language teaching: Challenges and barriers. In Proceedings of the $3 r d$ International Conference on e-Education, e-Business, e-Management and e-Learning (IC4E, 2012), IPEDR (Vol. 27, pp. 215-219).

Salehi, H., Shojaee, M., \& Sattar, S. (2014). Using E-Learning and ICT Courses in Educational Environment: A Review. English Language Teaching, 8(1), p63.

Salehi, H., Yunus, M. M., \& Salehi, Z. (2012). Teachers' perceptions of motivating factors to use ICT in the classroom. Journal of Applied Sciences Research, 8(3), 1654-1657.

Sekiguchi, S. (2012). Investigating the effects of Twitter on developing a social learning environment to support Japanese EFL students' self-regulated learning.

Selwyn, N. (2009). Faceworking: exploring students' education-related use of Facebook. Learning, Media and Technology, 34(2), 157-174. 
Shin, D., \& Nation, P. (2008). Beyond single words: The most frequent collocations in spoken English. ELT Journal, 62(4), 339-348.

Sinclair, J. (1991). Corpus, concordance, collocation. Oxford University Press.

Skrzypek, A. (2009). Phonological short-term memory and L2 collocational development in adult learners. EUROSLA Yearbook, 9(1), 160-184.

Smadja, F. A. (1989). Lexical co-occurrence: The missing link. Literary and Linguistic Computing, 4(3), 163-168.

Smith, C.2005, The lexical approach: collocation in high school English learners. George Fox University.

Smith, S., Salaway, G., \& Borreson Caruso, J. (2009). The ECAR study of undergraduate students and information technology, 2009 (Research Study, Vol. 6). Boulder, CO: EDUCAUSE Center for Applied Research.

Srinivas, R. (2010). ICT Tools for ELT Ppt Presentation-Author Stream.

Stowe Jr, W. A. (2013). Comparison of learning performance between students who do and students who do not use mobile technology-based activities. UNIVERSITY OF NORTH TEXAS.

Susilo, A. (2014). Exploring Facebook and Whatsapp As Supporting Social Network Applications For English Learning In Higher Education.

Sutee, J., \& Efparaxia. (2014). Investigating the adoption and use of smartphones in the UK: a silver-surfers perspective. (UH Business School Working Paper). University of Hertfordshire.

Sweeny, S. M. (2010). Writing for the instant messaging and text messaging generation: Using new literacies to support writing instruction. Journal of Adolescent \& Adult Literacy, 54(2), 121-130.

Sykes, J. M., Oskoz, A., \& Thorne, S. L. (2013). Web 2.0, synthetic immersive environments, and mobile resources for language education. Calico Journal, 25(3), 528-546.

Taylor, L. (2005). Teaching and learning vocabulary. Upper Saddle River, NJ: Prentice Hall.

Thornton, P. \& Houser, C. (2005). Using Mobile Phones in English Education in Japan. Journal of Computer Assisted Learning, 21, 217-228.

Towell, R., Hawkins, R., \& Bazergui, N. (1996). The development of fluency in advanced learners of French. Applied Linguistics, 17(1), 84-119.

Traxler, J. (2007). Defining, Discussing and Evaluating Mobile Learning: The moving finger writes and having write. The International Review of Research in Open and Distributed Learning, 8(2).

Trentin, G., \& Repetto, M. (2013). Using network and mobile technology to bridge formal and informal learning. Elsevier.

Trucano, M. (2005). Knowledge maps: ICTs in education. Washington, DC: infoDev/World Bank. Retrieved from http://www. infodev. org/en/Publication.

Truscott, J. (2007). The effect of error correction on learners' ability to write accurately. Journal of Second Language Writing, 16(4), 255-272.

UnitedNations2013,DeputySecretaryEliasson.www.un.org/apps/news/story.asp?NewsID=44452.

Vigotsky, L. (1978). Mind in society. Cambridge, MA: Harvard University Press.

Wagner, E. D., \& Wilson, P. (2005). Disconnected: Mobile learning responds to people who need access to information when out in the field or on the job. TAND D, 59(12), 40.

Wilkins, D. A. (1972). Linguistics and Language Teaching. London: Edward Arnold.

Woolard, G. (2000). Collocation-encouraging learner independence. Teaching Collocation: Further Developments in the Lexical Approach, 28-46.

Yalcinalp, S., \& Gulbahar, Y. (2010). Ontology and taxonomy design and development for personalised web-based learning systems. British Journal of Educational Technology, 41(6), 883-896.

Yeboah, J., \& Ewur, G. D. (2014). The impact of whatsApp messenger usage on students performance in Tertiary Institutions in Ghana. Journal of Education and Practice, 5(6), 157-164.

Yousefzadeh, M. (2012). Mobile-based learning vs. paper-based learning and collocation words learning. Journal of Educational \& Instructional Studies in the World, 2(3).

Yueng, K. (2013). Whatsapp Processed a Whopping (record) 18 billion messages on the last day of 2012. TNW News. Retrieved from www.thenextweb.com

Yunus, M. M., Salehi, H., \& Amini, M. (2015). Impact of Using CALL on Iranian EFL Learners' Vocabulary Knowledge. English Language Teaching, 9(1), 173.

Zareva, A. (2005). Models of lexical knowledge assessment of second language learners of English at higher levels of language proficiency. System, 33(4), 547-562.

Zhihong, L., Leijuan, H., \& Xiaohui, H. (2010).A research on a student-centered teaching model in an ICT-based English audio-video speaking class. International Journal of Education and Development using Information and Communication Technology, 6(3), 101-123. 